ПРЯМУХІНА

Наталія Валентинівна muha@gmail.com

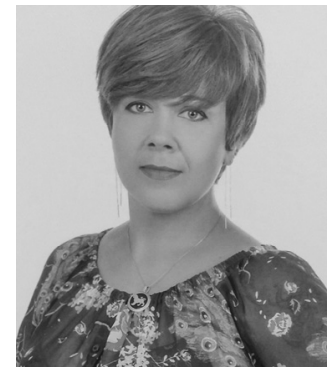

УДК 332.1

\section{ECOLOGICAL AND ECONOMIC COMPETITIVENESS: THE MODERN PARADIGM}

\section{ЕКОЛОГО-ЕКОНОМІЧНА КОНКУРЕНТОСПРОМОЖНІСТЬ: СУЧАСНА ПАРАДИГМА}

д.е.н., професор, зав. кафедри, Вінницький національний аграрний університет

PRIAMUKHINA Nataliia Valentynivna - Doctor of Economics, Professor, Head of department, Vinnytsia National Agrarian University

The article deals with the features of ecological and economic competitiveness at different levels of its realization. During the research the main levels of ecological and economic competitiveness were distinguished: national, regional and enterprise level. The main paradox was the justification that international ecological and economic competitiveness is realized through appropriate cooperation. At the same time, those countries that are involved in the projects later have the opportunity to implement them much more effectively, using the experience and resources of the already established international financial environmental funds. The study of the regional level of ecological and economic competitiveness makes it possible to clearly distinguish the competitive advantages and all participants of the subject-object relations. And the level of the enterprise, highlighted in the study, allows to influence certain components of ecological and economic competition. Accordingly, identifying the tools and techniques for such an impact may be of further scientific interest. The author outlines forms of international cooperation in the field of ecological and economic development, which results in an increase in the level of characteristics of competitive advantages of individual countries. The study of individual elements of historical genesis and geopolitical features of ecological and economic development has confirmed some of the author's assumptions. It is justified that the regional level is fundamental in the process of formation of ecological and economic competitive advantages, as it is a central element of subject-object relations in this field. The level of ecological and economic competitiveness of individual enterprises makes it possible to effectively implement appropriate measures of a point orientation, but a synergistic influence on the state of development of the country and the environment. As a result, the author formulates his own vision of the modern essence of ecological and economic competitiveness and competitive advantages at each determined level.

$* * *$

У статті розглянуто особливості еколого-економічної конкурентоспроможсності за різними рівнями ії реалізації. Виокремлено рівні екологічної та економічної конкурентоспроможності: начіональний, регіональний та підприємницький й обтрунтовано, шо міжнародна екологічна та економічна конкурентоспроможність реалізується за допомогою відповідної співпраці. Дослідження еколого-економічної конкурентоспроможності свідчить про розмежування конкурентних переваг всіх учасників економічних відносин. Рівень підприємства, на якому наголошено у дослідженні, дозволяє впливати на певні компоненти екологічної та економічної конкуренції. Відповідно, ідентифікачія інструментів та прийомів такого впливу представляє науковий інтерес. Автором окреслено форми міжннародної співпраці в галузі еколого-економічного розвитку, наслідком яких стає зростання рівня характеристик конкурентних переваг окремих країн. Дослідження окремих елементів історичного генезису та геополітичних особливостей еколого-економічного розвитку дозволило підтвердити деякі припущення автора. Обтрунтовано, щчо регіональний рівень є фундаментальним у прочесі формування еколого-економічних конкурентних переваг, оскільки виступає иентральним елементом суб'єктно-об'єктних відносин у даній сфері. Рівень еколого-економічної конкурентоспроможності окремих підприємств дозволяє ефективно впроваджувати відповідні заходи точковго спрямування, але синергетичного впливу на стан розвитку країни та навколишнього середовища. В результаті, автором сформульоване власне бачення сучасної сутності еколого-економічної конкурентоспроможності та конкурентних переваг за кожним означеним рівнем.

Keywords: ecology, economy, competition, cooperation, country, region, enterprise

Ключові слова: екологія, економіка, конкуренція, кооперація, краӥна, регіон, підприємство

\section{INTRODUCTION}

Issues of ecological situation in the world, climate change and careful nature management in modern conditions come to the fore in the development of any aspect of socio-economic life of society. Ecology of production processes is as important a feature of any business today as is its profitability or rentability. With the development of socio-economic ties and in the context of globalization processes, the environmental sustainability of economic development becomes an important feature of the investment attractiveness, progressiveness and innovation of not only an individual enterprise, but also the region or country in general. That is why the development of individual entities or their 
systems in modern conditions should be characterized as ecological and economic and cover the relevant specialized parameters, which makes the ecological and economic aspect of the presented research relevant. Competitiveness is a complex set of characteristics and properties of a particular subsystem among similar ones. Accordingly, it can be considered at different levels: enterprises, regions, countries, as well as a set of measures to ensure the environmental friendliness of economic processes.

The issues of determining the essence of competitiveness are considered in the works of I.V. Taranenko, M. Porter, K. Tyuz, P. Bush, H. Jorgnes. Some aspects of ecological and economic characteristics of individual systems are disclosed in the works of O. Tkach, O. Kostyshyn, N. Mikuli, O. Balatsky et.al. However, without diminishing the values of existing scientific achievements, it is still worth noting the need for modern scientific search for the essence of certain concepts, which is caused by the transformation of market conditions and scientific and technological development, the increase of the level of mutual integration of individual economic subsystems.

The PURPOSE of this research is to generalize theoretically and formulate the essence of environmental and economic competitiveness at different levels of economic activity.

\section{RESEARCH METHODS}

The methodological basis of the work is a set of methods of scientific knowledge, general scientific and special methods of research. The theoretical basis of the article is the position of economic theory, theory of regional development management, regional studies, strategic management of socio-economic development of regions, competitiveness, scientific works of domestic and foreign scientists in the field of ecological and economic development of regions and globalization.

\section{RESULTS}

For many centuries, humanity has used natural goods for its own purposes. Given the small population of the planet and the low or moderate development of technology, it was possible to maintain a balance of interests of society and the environment. But the development of industry and science, on the flip side, has provoked catastrophic environmental consequences of overcoming humanity only recently. At the end of the 20th - the beginning of the 21th century a considerable amount of both scientific achievements and normative regulation of ecological and economic aspects of activity of both individual enterprises and regions or countries as a whole has already been developed.

The peculiarity of international normative or directive acts of ecological and economic direction is their strategic nature and complexity. For example, the Kyoto rules are perpetual, but are constantly revised and modified in accordance to time and technology requirements. A considerable number of international environmental and economic directives involve the development of country-specific plans or measures, the creation of the necessary infrastructure and the investment climate.

However, it should be noted that the implementation of such as programs sometimes entails additional funding for them by specialized international funds, such as the
Life Fund, the Structural Funds, the Unity Fund and others, as well as the European Investment Bank lending facility [1]. However, such as financing is often not able to cover all the additional costs incurred in greening the economy or production processes.

Creating preconditions for ecological and economic development is not possible without the participation of the population. Specialized public organizations and entities actively control the environmental and economic activity of enterprises and state institutions, participate in the development of environmental programs, independently implement conservation or conservation measures. At the EU level, the Aarhus Convention on public access to information, participation in decision-making and environmental justice has even been approved [1]. In our opinion, the level of activity of such formations can serve as a kind of indicator of ecological and economic development of a country or region: the higher is the standard of living of the population, industrial efficiency, implementation of environmental standards, the more massive and frequent are environmental measures.

Ecological and economic competitiveness is realized through a set of measures aimed at conserving and restoring resources, water, air, forests, energy independence, etc. in forming the preconditions for sustainable economic development. At the same time the environmental problems in different countries or even regions are different. But the detrimental effect of the economy is similar: emissions and waste generation in the environment, greenhouse effect and exhaustion of non-renewable resources. Accordingly, the environmental needs of different countries differ significantly: for example, France's major environmental problems cover damage to forests by acid rain, high levels of air and fresh water pollution due to industrial activity and urbanization of the country [2]. Therefore, in order to ensure the competitiveness of its country, the government should direct its investments and efforts to these problems, creating appropriate competitive advantages: tourist attractiveness, successful geopolitical position, prestige of the country as a brand. That is, international cooperation is one of the instruments for ensuring the competitiveness of the participating countries. For example, a set of measures is being developed and implemented at EU level to address the low energy efficiency of industry in Hungary and significant amount of industrial waste [2].

Ecological and economic competitive advantages are gained not only by the current state of the environment, but also by the measures taken to overcome the damage already done or preventive measures. Management of the additional costs, carried by the government, local government and industry in terms of greening the economy are transformed by the potential increase in profitability due to the high level of competitiveness of the system and remote benefits from the environment, resource recovery, etc.

The process of forming the elements of ecological and economic competitiveness of particular countries, regions or enterprises is a natural continuation of the processes of economic development, but is carried out against the processes of convergence and globalization: the mutual penetration of economic subsystems aggravates their competition. All subsystems compete in the process of resource allocation, energy use, investment attraction. 
Combining the efforts of the individual countries' governments in one - ecological and economic - direction, on the one hand, harmonizes and enhances the effectiveness of individual measures, and on the other - creates for each individual participant a unique set of competitive advantages. Accordingly, ecological and economic competitiveness, as well as cooperation, can be realized at several levels (Fig. 1).

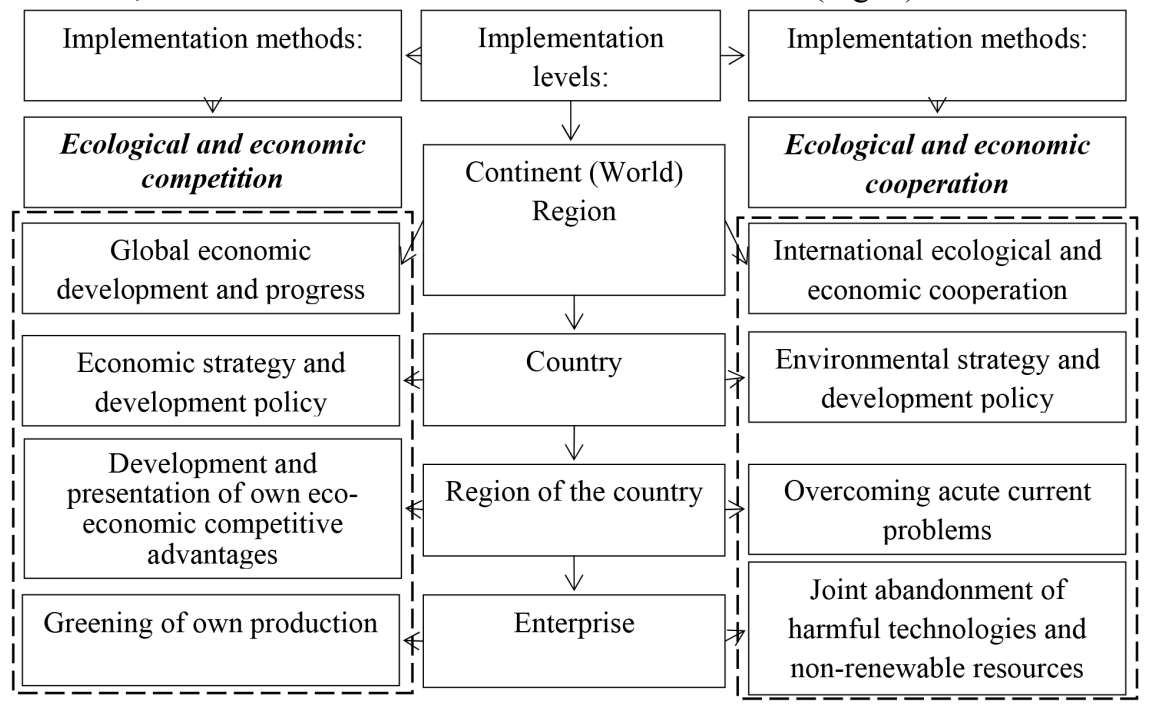

Fig.1. Levels of ecological and economic competitiveness

It should be noted that the participation of the entity (enterprises, region, country) doesn't yet indicate the environmental friendliness of its activities, and vice versa. For example, India is a participant of several international environmental agreements, but the traditions and habits of the population do not allow any improvement in the country's overall environmental status. At the same time, enterprises in this country do not demonstrate a desire to use renewable energy sources or resources [2].

Environmental technologies should be disseminated in society. These are know-how that should not be kept secret but should be disseminated to producers, consumers and other members of the public. That is, the country's or local government is interested in patenting environmental ideas with further redemption and dissemination. For these purposes local and state governments have the appropriate tools and levers of influence. For example, in Ukraine the environmental tax, that is set according to the amount of pollution involved, still requires strict regulation of the amount of emissions. And for their excess significant penalties are provided. That is, an enterprise cannot "buy" at the expense of tax a higher limit on discharges, but is stimulated for the installation of filtration plants or other forms of greening of production processes [3].

International co-operation, as a tool for creating ecoeconomic competitive advantages, allows governments to extrapolate the experience gained by others to their realities and thus avoid a number of mistakes and additional costs. Accordingly, competitive advantages are created faster and the effectiveness of the implementation of events can be much higher. That is, in the process of competition, "trailblazers" create the conditions for the development of the rest of the countries.

A detailed analysis of the historical experience of the implementation of international ecological and economic convergence and competition is presented in the works of I.V. Taranenko [1]. He notes that the first countries to implement environmental strategies at national level were the Netherlands and Denmark. They continued their ideas in Germany by developing eco-labels. Already then France and Austria connected with their eco-programs. The first environmental tax was introduced in Finland, and then gradually throughout the EU. This tax, as an instrument of ecological and economic governance, is still expanding in the world [1]. As we can see, those countries that are today one of the leaders of the world economic development, that is leaders in the realization of competitive advantages have become the leading ones in ecological and economic development. However, despite the high level of environmental awareness of the population in these countries, the environmental friendliness of manufacturing technologies and the high government spending on appropriate targeting, the industry has already caused their ecosystems such catastrophic consequences that will be overcome for generations to come.

The regional level of environmental and economic competitiveness is a testament to the implementation of state policy in this field. All regions of the country form a synergistic system that operates in a single strategic direction, but have their own peculiarities. So, Bologna and Sicily have their own peculiarities of both economic characteristics and environmental problems. Accordingly, the environmental and economic competitive advantages of different regions must be different, regardless of their nationality or assessment parameters. So, the availability of resources is an advantage of the Donbass in the heavy industry, which is much more significant than the level of air or water pollution. But the western and northern regions of the country are much more attractive to the farm because of cleaner soils and water, which serve as the basis of forage and yield.

Therefore, the regional level of ecological and economic competitiveness can be considered fundamental, because, on the one hand, it is characterized by strategic measures, agile tactics, and on the other hand is adaptive and takes into account the needs of all participants in social reproduction. Ecological and economic development 
of regions and shapes their competitive advantages in the fight for investment, government subsidies, allocation of productive forces and more. The indirect consequence of the formation of ecological and economic competitive advantages of the region is the improvement of the standard of living of the population, as the preconditions for the development of industry are formed against the background of its high technology and efficiency. In doing so, environmental improvements should be ensured. Targeting the environmental tax can overcome the effects of the harmful effects of industry, and the activities of local governments - to respond promptly to changes in environmental and economic competitiveness.

The regional level of ecological and economic competitiveness, being at the center of subject-object relations in this field, can ensure the correct orientation, harmonization and synergy of measures from individual enterprises to public policy. Thus, the role of the regional level is transformed: from the connecting link to the central element (Fig. 2).

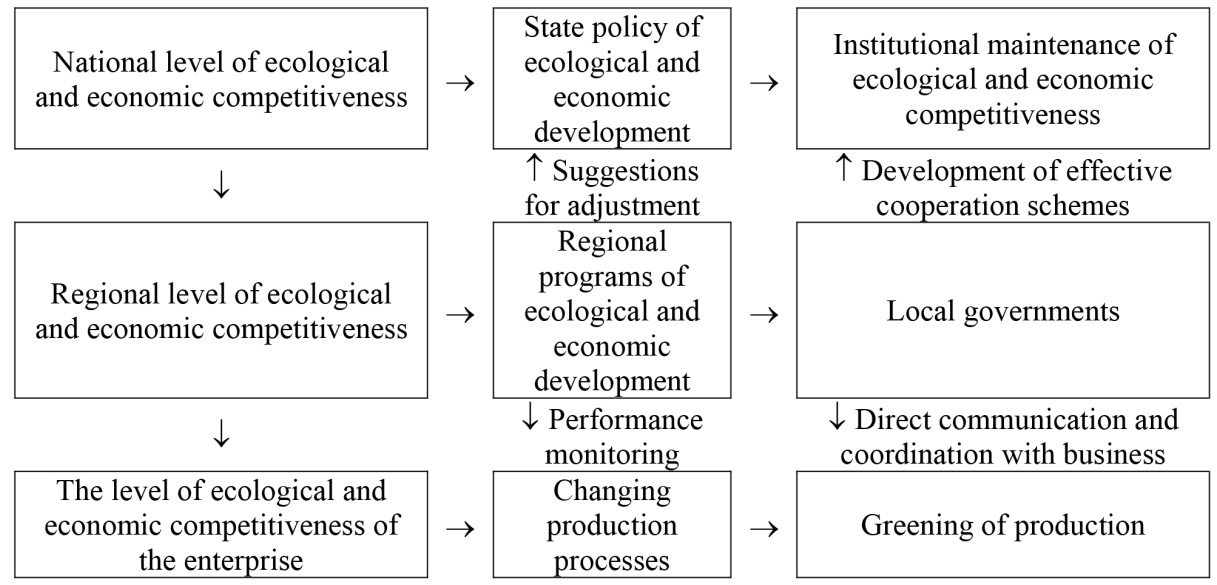

Fig. 2. The role of regions in shaping ecological and economic competitiveness

At the regional level a separate economic subsystem is formed, which although it does not carry out direct self-management, but performs a number of specific functions. Accordingly, the ecological and economic competitiveness of an individual region should be characterized by the following parameters:

- living standards of the population;

- soil contamination level;

- fresh water contamination level;

- the level of air pollution;

- use of renewable energy resources;

- restoration / planting of forests and lands;

- industrial production volumes; balance of payments of the region;

- use of electric transport in the region (public and private);

- expenditures of local budgets for implementation of environmental measures;

- received state subsidies for environmental programs;

- effectiveness of environmental programs and activities, etc.

The above list is not exhaustive and contains only the most important, in our opinion, characteristics.

The regional level of ecological and economic competitiveness, while serving as a basic element of a complex system, is nevertheless formed from the components of a separate business. The task of local self-government bodies is to create favorable conditions, stimulate and support certain environmental measures by entrepreneurs. So, local authorities can create communication platforms for the population and business, carry out educational and publicity work. However, the implementation of smart environmental management measures will be undertaken directly by businesses. That is why the ecological and economic competitiveness at the enterprise level is realized by concrete steps: waste filtering, modernization of equipment and technologies, energy efficiency, etc.

Therefore, as a result of the research, we can distinguish between the concept of ecological and economic competitiveness and the corresponding competitive advantages by the levels of their realization.

Ecological and economic competitiveness at the national level is the ability of a country to generate and implement effective environmental and economic policies within the framework of relevant international cooperation at the global level. The ecological and economic competitive advantages of an individual country are the level of development of the economy as a whole, the standard of living of the population of that country and the state of the environment. These benefits are generated through the introduction and continuous promotion of a range of environmental measures, international environmental programs, the development of science, technology and technology. In other words, competitive advantage is not only about the availability or availability of resources, but also the ability to use them effectively and carefully.

Ecological and economic competitiveness at the regional level is the ability of an individual region to implement public policy in conjunction with local business development. Ecological and economic competitive advantages of the region are its resources, energy independence, industrial and logistic development, infrastructure for business development and implementation of eco projects, institutional support for greening production and more. An important element of the ecological and economic competitiveness of individual regions is the activity of its territorial community, environmental awareness and culture of the population.

Ecological and economic competitiveness at the enterprise level is its complex characteristic as an effective economic entity, which minimizes its harmful impact on 
the environment. Ecological and economic competitive advantages of an individual enterprise will be its investment attractiveness, profitability, environmental friendlyness, low (minimized) level of harmful influence on the environment, ecological modernization of the range, products and technologies of its production. Particular attention should be paid to the enterprise's involvement in environmental processes and activities in the region.

\section{CONCLUSIONS}

During the research the main levels of ecological and economic competitiveness were distinguished: national, regional and enterprise level. The ecological and economic competitiveness realization through appropriate cooperation is justified. At the same time those countries that are involved in the projects later have the opportunity to realize the outcomes of that projects much more effectively, using the experience and resources of the already established international financial environmental funds. The research of the regional level of ecological and economic competitiveness makes it possible to clearly distinguish the competitive advantages and all participants of the subject-object relations. And the level of the enterprise, highlighted in the study, allows to influence certain components of ecological and economic competition. Accordingly, identifying the tools and techniques for such an impact may be of further scientific interest.

\section{$\underline{\text { References }}$}

1. Taranenko I.V. Analysis of ecological and economic aspects of international competitiveness of countries. Economic space. 2014. № 92. pp. 69-77 [in Ukrainian].

2. Index mundi. Country Facts Explorer. URL: http://www.indexmundi.com/

3. Tax Code of Ukraine: Verkhovna Rada of Ukraine, dated December 2, 2010 №2755-VI. URL: https://zakon.rada.gov.ual laws/show/2755-17 [in Ukrainian].

4. Tkach O.V., Mikula N.A. Regional spatial and economic systems: current status and development prospects: monograph. Lviv: IRD NAS of Ukraine, 2012. 236 p. [in Ukrainian].
5. Kostyshyn O.O. Ecological and economic principles of rational land use in regional economic systems: abstract. diss. ... cand. econom. sciences: 08.00.06 / NAU. Lviv, 2012. 20 p. [in Ukrainian].

6. Tews K., Busch P.O., Jorgens H. The Diffusion of new Environmental Policy Instruments. European Journal of Political Research. URL: http://userpage.fuberlin.delfful download/rep_02-01.pdf

7. EU Environmental Policies: A short history of the policy strategies. URL: http://www.eeb.org/publication/chapter-3.pdf

8. Georges K., Jun D. The challenge of the implementation of the environmental Acquis Communautaire in the new member states. URL: http://www.inece.org/conference/7/vol2/ 59_Kremlis.pdf

\section{Список використаних джерел}

1. Тараненко I.В. Аналіз еколого-економічних аспектів міжнародної конкурентоспроможності крайн. Економічний простір. 2014. № 92. С. 69-77.

2. Index mundi. Country Facts Explorer. URL: http://www.indexmundi.com/

3. Податковий кодекс Украӥни: Верховна Рада Украӥни, від 02.12.2010 №2755-VI. URL: https://zakon.rada.gov.ual laws/show/2755-17

4. Ткач О.В., Мікула Н.А. Регіональні просторово-економічні системи: сучасний стан та перспективи розвитку : монографія. Львів : ІРД НАН Украӥни, 2012. 236 с.

5. Костишин О.О. Еколого-економічні засади раціонального землекористування в регіональних господарських системах: автореф. дис. ... канд. екон. наук: 08.00.06 / НАУ. Львiв, 2012. 20 c.

6. Tews K., Busch P.O., Jorgens H. The Diffusion of new Environmental Policy Instruments. European Journal of Political Research. URL: http://userpage.fuberlin.de/fful download/rep_02-01.pdf

7. EU Environmental Policies: A short history of the policy strategies. URL: http://www.eeb.org/publication/chapter-3.pdf

8. Georges K., Jun D. The challenge of the implementation of the environmental Acquis Communautaire in the new member states. URL: http://www.inece.org/conference/7/vol2/ 59_Kremlis.pdf 